\title{
PENGUASAAN LEKSIKON ARKAIS BAHASA MELAYU AMBON DI KALANGAN PEMUDA DI KOTA AMBON
}

\section{ARCHAIC LEXICON MASTERY OF AMBON MALAY LANGUAGE AMONG YOUTH IN THE CITY OF AMBON}

\author{
Erniati \\ Kantor Bahasa Maluku \\ Pos-el: erniati.kemdikbud@gmail.com
}

\begin{abstract}
Abstrak
Kondisi bahasa-bahasa daerah di Maluku saat ini semakin berkurang penuturnya. Ini terjadi karena adanya hubungan kausatif dengan sikap dan pilihan penutur terhadap bahasa dan eksistensi bahasa Melayu Ambon. bahasa Melayu Ambon adalah bahasa pengantar dalam komunikasi informal antaretnis di Maluku. bahasa Melayu Ambon sebagai suatu anasir yang terbentuk akibat proses asimilasi yang panjang dalam kurun waktu lama tak dapat dipungkiri turut menyerap sebagian besar kosakata dari bahasa Portugis, bahasa Belanda, serta bahasabahasa daerah setempat. Dalam perkembangannya, berbagai faktor eksternal seperti sikap bahasa, minat bahasa, preferensi, serta pewarisan register bahasa dalam berbagai tataran disinyalir telah menyebabkan semacam proses 'arkaisme' atau 'penuaan' terhadap kosakata tertentu, terutama kosakata yang berasal atau mendapat pengaruh dari bahasa-bahasa Eropa dan bahasa daerah. Ketika kebutuhan menyampaikan makna dalam leksikon, frasa, dan kalimat dalam satu bahasa tidak sebanding dengan penguasaan kosakata yang ada, maka penutur cenderung menggantikan unsur-unsur tersebut dengan leksikon dan frasa dari bahasa yang berada pada tingkatan atau ragam yang lebih rendah/ informal. Pada akhirnya, penggunaan leksikon dan kosakata dari bahasa-bahasa daerah atau bahasa-bahasa tua perlahan-lahan mulai tergantikan oleh unsur-unsur dari bahasa yang lebih modern, atau yang menduduki fungsi normatif dalam komunikasi oleh pemakai bahasa tersebut. Penelitian ini merupakan jenis penelitian eksperimental dengan menggunakan pendekatan kuantitatif. Tujuan penelitian ini diharapkan akan dapat mengukur penguasaan leksikon arkais pada kelompok usia pemuda yakni dalam tataran mikrolinguistik dan mengidentifikasi penguasaan leksikon arkais pada tataran morfologis sintaksis, dan semantik. Hasil penelitian menunjukkan bahwa penguasaan leksikon arkais kedua desa tersebut berada pada kategori kurang baik.
\end{abstract}

Kata kunci: leksikon, arkais, bahasa Melayu Ambon

\begin{abstract}
The condition of the regional languages in Maluku is currently diminishing in speakers. This happened because of the causative relationship with the attitudes and choices of speakers about the language and the existence of Ambonese Malay. Ambon Malay Language is the language of instruction in interethnic informal communication in Maluku. Ambon Malay language as a factor formed by a long process of assimilation over a long period of time is undeniably absorbing most of the vocabulary from Portuguese, Dutch, and local languages. In its development, various external factors such as language attitudes, language interests, preferences, and inheritance of language registers in various levels were alleged to have caused a kind of 'archaism' or 'aging' process towards certain vocabulary, especially vocabulary originating from or influenced by European languages and regional languages. When the need to convey meaning in lexicons, phrases, and sentences in one language is not proportional to the mastery of the existing vocabulary, speakers tend to replace these elements with lexicons and phrases from languages that are at a lower level or variety / informal. In the end, the use of lexicons and vocabulary from
\end{abstract}


regional languages or old languages slowly began to be replaced by elements from more modern languages, or which occupy normative functions in communication by users of that language. This study is a type of experimental research using a quantitative approach. The purpose of this study is expected to be able to measure the mastery of archaic lexicons in the youth age group, namely in the microlinguistic level and identify mastery of archaic lexicons at the syntactic, semantic morphological level. The results showed that the mastery of the archaic lexicon in the two villages was in the poor category.

Keywords: lexicon, archaic, Malay Ambon language

\section{Pendahuluan}

Kondisi objektif berbagai bahasa daerah di Indonesia dewasa ini, terutama bahasa-bahasa daerah yang berkedudukan sebagai bahasa ibu maupun bahasa kedua, semakin menunjukkan kecenderungan untuk mengalami penurunan jumlah penutur. Berkurangnya jumlah penutur secara simultan dapat membawa bahasabahasa daerah tersebut ke arah kematian, bahkan kepunahan bahasa. Grimes (2002: 1) dalam Latupapua (2013) menyatakan bahwa punahnya suatu bahasa berarti punahnya suatu lingkungan manusia yang unik dari muka bumi.

Beberapa kajian ilmiah dan penelitian yang dilakukan oleh berbagai pihak menunjukkan hasil yang relevan. Hasil penelitian menunjukkan bahwa, secara khusus, bahasa-bahasa daerah dan atau bahasa-bahasa lokal di Maluku telah mengalami penurunan atau pemunduran yang amat signifikan, terkait dengan persebaran penutur dan ranah penggunaan bahasa yang cenderung menyempit. Selain itu, eksistensi anasir-anasir budaya dan sastra yang inklusif dalam bahasa sebagai media komunikasi sosiobudaya semakin berkurang dan menurun penguasaannya di dalam lingkungan pemiliknya, seiring melemahnya proses transformasi atau pewarisan antargenerasi.

Hasil penelitian Latupapua, dkk. (2013) mengenai Pemertahanan bahasa Tana sebagai bahasa Adat di Kabupaten Maluku Tengah bahwa status bahasa Tana sebagai bahasa tua yang digunakan dalam ranah ritual berada pada kategori critically endangered language, yakni tahapan sangat kritis dan memerlukan perawatan yang sangat serius. Hal demikian disebabkan karena penutur dan pencerita yang menggunakan bahasa tersebut dalam ritual adat semakin berkurang jumlahnya, sementara proses pewarisan teks sastra lisan yang dituturkan dalam ritual dengan menggunakan bahasa Tana tidak berjalan dengan baik, terutama upaya pewarisan yang melibatkan generasi muda.

Penyebab penting lainnya yang dapat dijelaskan di sini adalah munculnya fenomena kebocoran diglosia yang terkait dengan penggunaan bahasa dalam hirarki atau tingkatan dan ranah yang berbeda-beda. Ketika kebutuhan menyampaikan makna dalam leksikon, frasa, dan kalimat dalam satu bahasa tidak sebanding dengan penguasaan kosakata yang ada, penutur cenderung menggantikan unsur-unsur tersebut dengan leksikon dan frasa dari bahasa yang berada pada tingkatan atau ragam yang lebih rendah/ informal. Pada akhirnya, penggunaan leksikon dan kosakata dari bahasa-bahasa daerah atau bahasa-bahasa tua perlahan-lahan mulai tergantikan oleh unsur-unsur dari bahasa yang lebih modern atau yang menduduki fungsi normatif dalam komunikasi oleh pemakai bahasa tersebut (Latupapua, dkk, 2013: 89).

Kondisi bahasa-bahasa daerah di Maluku semakin berkurang penuturnya tersebut memiliki hubungan kausatif dengan sikap dan pilihan penutur terhadap bahasa dan eksistensi bahasa Melayu Ambon (selanjutnya disingkat BMA). BMA adalah bahasa pengantar dalam komunikasi informal antaretnis di Maluku. Sementara itu, bahasa Indonesia (selanjutnya disingkat $\mathrm{BI}$ ) digunakan dalam ranah komunikasi formal. Oleh sebab BMA dan BI telah mengambil alih sebagian besar peran sebagai wahana komunikasi utama dalam lingkungan penutur, peran bahasa-bahasa lain termasuk bahasa daerah dan bahasa etnik dapat diasumsikan semakin melemah dari segi 
pilihan penutur terhadap bahasa tertentu dalam ranah penggunaan tertentu. Ada beberapa kosakata arkais BMA yang tidak lagi digunakan di kalangan anak muda, misalnya:

1. /hetu/ [menceritakan orang],

2. /parsiram/ [menghiasi pelaminan]

3. /reinkam/ [jepitan rambut]

4. /kartouw/ [celana pendek]

5. /langsam/ [pelan-pelan]

BMA sebagai suatu anasir yang terbentuk akibat proses asimilasi yang panjang dalam kurun waktu lama tidak dapat dipungkiri turut menyerap sebagian besar kosakata dari bahasa Portugis, bahasa Belanda, serta bahasa-bahasa daerah setempat. Dalam perkembangannya, berbagai faktor eksternal seperti sikap bahasa, minat bahasa, preferensi, serta pewarisan register bahasa dalam berbagai tataran disinyalir telah menyebabkan semacam proses 'arkaisme' atau 'penuaan' terhadap kosakata tertentu, terutama kosakata yang berasal atau mendapat pengaruh dari bahasa-bahasa Eropa dan bahasa daerah atau bahasa lokal.

Menurut Kamus Besar Bahasa Indonesia, kata 'arkais' atau 'arkais' memiliki makna (1) berhubungan dengan masa dahulu atau berciri kuno, tua; (2) tidak lazim dipakai lagi (kata); ketinggalan zaman. Lebih lanjut, menurut Omar (1991), kata-kata arkais merupakan kata-kata yang tidak lagi digunakan pada hari ini, yang penggunaannya semakin usang. Proses 'menjadi tua'-nya kata-kata dalam suatu bahasa disebabkan pengaruh modernisasi bahasa yang semakin ketat dan pesat seiring dengan perkembangan zaman dan perkembangan masyarakat. Akan tetapi, ia menambahkan, kata-kata arkais ini dapat terus hidup dalam penggunaan yang terhadap (terbatas) oleh kalangan istana.

Berbeda dengan pendapat di atas, Soekamto (1985: 72) menjelaskan bahwa archaism atau bahasa arkais adalah tuturan yang digunakan dengan menggunakan unsurunsur dari zaman lampau dan tetap bertahan.

Beberapa definisi arkais tersebut menjadi acuan dalam penelitian ini. Penelitian ini melibatkan kelompok usia pemuda. Usia pemuda yang dimaksudkan ialah menurut definisi Undang-Undang RI Nomor 40 Tahun 2009. Pemuda adalah warga negara Indonesia yang memasuki periode penting pertumbuhan dan perkembangan yang berusia 16 (enam belas) sampai 30 (tiga puluh) tahun.

Perihal pemilihan kelompok usia pemuda sebagai subjek penelitian berdasarkan pada asumsi faktual bahwa pada usia pemuda, sebagai kontraposisi dari kelompok usia tua (orang tua), mungkin terjadi penurunan penguasaan kosakata yang amat signifikan sebagai akibat kontak yang amat kuat dengan bahasa selain bahasa ibu, maupun oleh sebab faktor-faktor ekstralinguistik lainnya. Hal demikian dapat diamati melalui keterpengaruhan oleh bahasa selain bahasa ibu dalam ranah pendidikan dan ranah pergaulan sehari-hari. Pada sisi yang lain, kelompok pemuda merupakan generasi pewaris yang seharusnya mengemban fungsi penting sebagai pewaris anasir-anasir kebudayaan, termasuk bahasa.

Pengamatan empiris dan uji instrumen terhadap para responden yang dilakukan dalam studi awal penelitian ini menunjukkan bahwa penguasaan leksikon yang tergolong arkais sudah mulai melemah dan mulai berkurang penguasaannya dalam register bahasa sebagian penutur BMA (Latupapua, 2015). Artinya, leksikon-leksikon yang tergolong tua dan arkais tersebut secara perlahan-lahan mulai menghilang dari register BMA.

Fenomena tersebut dapat dijadikan sebagai dasar pijak asumtif untuk menarik benang merah antara perubahan register bahasa, nilai-nilai sosial budaya, dan pilihan bahasa secara makro maupun mikro. Dalam kaitan dengan itu, pemuda adalah kelompok usia yang paling krusial dan rentan terhadap menurunnya sikap positif dan minat terhadap anasir-anasir kebudayaan lokal, termasuk bahasa lokal, bahasa-bahasa budaya, bahasabahasa tua, maupun kesanggupan untuk mempelajari dan menggunakan semua unsur kebahasaan itu. Dengan berkurangnya penguasaan leksikon-leksikon tersebut dapat dikatakan eksistensi BMA pada salah satu segi, yakni sebagai alat komunikasi dengan fungsi pembawa kode-kode budaya setempat juga ikut melemah.

Kajian ini akan diarahkan pada pengukuran kuantitatif untuk mengetahui 
penguasaan leksikon arkais pada penutur BMA di beberapa desa atau negeri yang dipilih dengan prosedur tertentu. Beberapa desa atau negeri dimaksud sekaligus merupakan lokus penelitian, yakni pada wilayah Kecamatan Sirimau, Kota Ambon. Wilayah Kecamatan Sirimau dipilih dengan asumsi bahwa wilayah Kecamatan Sirimau terletak di pusat kota yang keadaan masyarakat dan profil kebahasaannya sangat majemuk dan dinamis. Hal itu menyebabkan pengukuran terhadap penguasaan kosakata arkais di kalangan pemuda akan menjadi hal yang penting untuk dilakukan.

Dalam perkembangan selanjutnya, ditinjau dari aspek keterjangkauan dan heterogenitas responden, rentang cakupan responden dibatasi pada tiga negeri di wilayah Kecamatan Sirimau, yakni Negeri GalalaNegeri Hative Kecil, serta Negeri Batu Merah. Pembatasan responden hanya pada ketiga negeri ini didasarkan pada alasan-alasan mendasar, yakni: (1) jumlah penduduk dan persebaran penduduk Kecamatan Sirimau terlalu banyak dan luas, tetapi cenderung homogen; (2) berdasarkan homogenitas karena dalam konteks penelitian ini Negeri GalalaHative Kecil (selanjutnya disebut demikian) dianggap sebagai kelompok homogen dan beroposisi dengan Negeri Batu Merah yang cukup heterogen secara linguistik dan etnis; (3) Rata-rata penduduk di kedua kelompok masyarakat tersebut menganut agama berbeda. Penduduk Negeri Galala-Hative Kecil mayoritas Kristen, sedangkan penduduk Negeri Batu Merah nyaris seluruhnya beragama Islam. Hal ini dipercaya sebagai faktor pembeda yang memengaruhi aspek yang diteliti dan akan terlihat pada hasil penelitian.

Berdasarkan latar belakang di atas, masalah penelitian ini akan terfokus pada penguasaan leksikon arkais pada kalangan usia pemuda di wilayah administratif Kecamatan Sirimau, Kota Ambon. Penguasaan diksi leksikon arkais tersebut berkaitan erat dengan keberadaannya dalam register BMA serta penggunaannya dalam satuan-satuan linguistik berbentuk kata dan frasa (morfologi), maupun dalam satuan yang lebih luas, yakni kalimat dan wacana.

Selain aspek-aspek mikrolinguistik tersebut di atas, masalah penelitian ini juga akan diarahkan pada aspek-aspek makrolinguistik. Aspek makrolinguistik dimaksud ialah sikap bahasa penutur terkait dengan persoalan pilihan dan ranah penggunaan bahasa yang diasumsikan turut memengaruhi penguasaan dan penggunaan leksikon arkais BMA tersebut.

Tujuan penelitian ini diharapkan akan dapat mengukur penguasaan leksikon arkais pada kelompok usia pemuda, yakni dalam tataran mikrolinguistik dan mengidentifikasi penguasaan leksikon arkais pada tataran morfologis, sintaksis, dan semantik. Di sisi lain, penelitian ini diharapkan memberikan manfaat terhadap akumulasi teori dan konsep fundamental dari arkaisme bahasa, teori sosiolinguistik dalam konteks BMA, teori tentang struktur bahasa, leksikon arkais, serta muatan budaya lokal di dalamnya.

\section{Metode}

Penelitian ini merupakan jenis penelitian eksperimental dengan menggunakan pendekatan kuantitatif. Menurut Sugiyono, metode penelitian kuantitatif dapat diartikan sebagai metode penelitian yang berlandaskan pada filsafat positivisme dan digunakan untuk meneliti populasi atau sampel tertentu. Teknik pengambilan sampel pada umumnya dilakukan secara random, pengumpulan data menggunakan instrumen penelitian, analisis data bersifat kuantitatif/statistik dengan tujuan untuk menguji hipotesis yang telah ditetapkan (Sugiyono, 2012: 7).

Dengan demikian, analisis data penelitian pendekatan kuantitatif digunakan untuk melakukan perhitungan data. Data dijaring dari responden secara statistik dengan menggunakan rumus atau formula relevan, terutama terhadap data-data hasil tes dengan menggunakan instrumen yang telah disiapkan sebelumnya. Melalui pengukuran kuantitatif akan diperoleh informasi eksak dan terpercaya yang dapat digunakan untuk kepentingankepentingan teoretis maupun praktis. 


\subsection{Populasi}

Menurut Arikunto (2005: 112), populasi adalah keseluruhan objek penelitian. Jadi, populasi berkaitan dengan objek-objek, baik manusia, nilai-nilai tes, benda-benda, atau peristiwa-peristiwa yang menjadi fokus penelitian. Dengan demikian, yang menjadi populasi penelitian ini adalah seluruh pemuda dalam wilayah administratif Kecamatan Sirimau, Kota Ambon.

\subsection{Sampel}

Sampel adalah bagian dari populasi yang mewakili keseluruhan populasi. Menurut Rustanto (2010: 35), jika subjek penelitian kurang dari 100, subjek penelitian tersebut sebaiknya diambil keseluruhannya dan penelitian tersebut merupakan penelitian populasi. Akan tetapi, jika subjek penelitian berjumlah lebih dari 100 maka sampelnya dapat ditentukan $10 \%-15 \%$ atau 20\%-25\%. Karena jumlah subjek penelitian dalam populasi ini dimungkinkan lebih dari 100, sampel penelitian ini ialah $25 \%$.

Penelitian ini menggunakan teknik purpossive sampling, yakni penarikan sampel bertujuan, dipadukan dengan pengambilan sampel secara acak. Purpossive sampling dilakukan dengan memilih 2 (dua) desa/negeri dalam wilayah administratif Kota Ambon kemudian pemilihan sampel pada ketiga negeri itu dilakukan secara acak sesuai kriteria jumlah sampel di atas.

Penelitian ini dilaksanakan dengan memilih secara acak sebanyak masing-masing 100 responden dari Negeri Batu Merah dan 100 responden dari Negeri Galala-Hative Kecil. Penentuan masing-masing kelompok responden dilakukan secara acak dan manasuka, dengan berpatokan pada kriteria kelompok usia dan domisili, seperti yang telah diancangkan sebelumnya. Secara keseluruhan penelitian ini dilaksanakan terhadap 200 responden dari kedua negeri yang merepresentasikan dua masyarakat bahasa yang sama-sama menuturkan bahasa Melayu Ambon, namun memiliki karakteristik yang berbeda satu dengan yang lain.

\subsection{Variabel}

Menurut Hatch and Faraday (1981: 87) variabel penelitian adalah atribut dari seseorang atau objek tertentu yang mempunyai variasi antara satu dengan lainnya. Variabel penelitian juga merupakan konstruksi atau sifat yang akan dipelajari dari suatu fenomena.

Dalam kaitan dengan penelitian ini, variabel yang akan menjadi fokus adalah variabel tunggal, yakni penguasaan leksikon arkais bahasa Melayu Ambon. Kajian terhadap variabel tersebut dilakukan melalui pengujian terhadap indikator-indikator sebagai berikut: (1) aspek morfologis, (2) aspek sintaksis, dan (3) aspek semantik pada kalangan pemuda di wilayah administratif Kecamatan Sirimau, Kota Ambon. Selanjutnya, hasil pengujian indikator akan dibahas dalam kaitan dengan faktor-faktor makrolinguistik yang relevan dengan temuan pada rersponden penelitian.

Pengumpulan data dalam penelitian ini menggunakan teknik-teknik tertentu, seperti yang dikemukakan berikut ini.

(1) Teknik observasi, yakni melakukan pengamatan langsung terhadap subjek penelitian.

(2) Teknik tes, yakni memberikan tes berupa butir soal-soal tertutup berbentuk pilihan ganda untuk menguji penguasaan terkait dengan objek formal penelitian. Instrumen butir soal akan diuji validitasnya terlebih dahulu sebelum diberlakukan kepada subjek yang menjadi sampel penelitian.

Terkait dengan teknik pengumpulan data yang telah dikemukakan di atas, instrumen yang digunakan selama pengumpulan data meliputi catatan observasi dan butir-butir soal.

Analisis data menurut Patton (2005: 46) adalah proses mengatur urutan data dan mengorganisasikannya dalam suatu urutan pola, kategori, dan satuan uraian dasar. Sementara itu, penafsiran data menurutnya adalah memberikan arti secara signifikan terhadap hasil analisis, menjelaskan pola-pola uraian, serta mencari hubungan di antara dimensi-dimensi uraian.

Dalam penelitian ini, analisis data berlangsung sesudah pengumpulan data selesai dilakukan. Berdasarkan uraian di atas maka 
analisis data dapat dilakukan melalui langkahlangkah, sebagai berikut.

1. Menyusun data berdasarkan kategori (data tes dan data kuesioner).

2. Melakukan triangulasi teori dan triangulasi sumber untuk memverifikasi data.

3. Mengadakan pengukuran dan penghitungan terhadap data dengan formula yang telah ditentukan.

4. Menjelaskan hasil pengukuran kuantum data.

5. Merumuskan kesimpulan.

Pada tahap pertama, pengukuran terhadap variabel pada subjek yang menjadi sampel penelitian akan dilakukan terhadap data dengan menggunakan formula atau rumus, sebagai berikut.

\begin{tabular}{|l|}
\hline F \\
- X 100 \\
N
\end{tabular}

Keterangan:

$\mathrm{F}=$ Jumlah jawaban yang dipilih

$\mathrm{N}=$ Jumlah responden

$100=$ Bilangan tetap

(Sudjana, 1987: 172)

Selanjutnya, teknik tes dilakukan dengan menggunakan butir soal berbentuk pilihan ganda terstandard. Skor atau nilai setiap subjek sampel ditentukan dengan menggunakan rumus tebakan $(\mathrm{S}=\mathrm{R}), \mathrm{S}$ adalah skor atau nilai, sedangkan $\mathrm{R}$ adalah jawaban benar.

Selanjutnya, pengukuran terhadap variabel terikat, yakni data tes dilakukan dengan menggunakan statistika sederhana dengan rumus di bawah ini:

\begin{tabular}{|c|}
\hline$X X$ \\
$X=$ \\
$N$
\end{tabular}

Keterangan:

$\mathrm{X}=$ Jumlah nilai rata-rata kelas (Mean)

$\sum \mathrm{X}=$ Jumlah seluruh skor

$\mathrm{N}=$ Jumlah Subjek

(Tarsis Tarmudji, 2008: 65)

Setelah skor rata-rata diperoleh melalui penggunaan rumus di atas,akan ditentukan klasifikasi penilaian dengan menggunakan skala seperti yang dikemukakan oleh Nurgiyantoro (2007: 75). Skala ini perlu digunakan untuk menentukan rentang skor dan kategori-kategori tertentu yang berhubungan dengan hasil penelitian atau pengukuran kuantum. Skala yang digunakan dalam klasifikasi penilaian hasil tes rersponden adalah seperti yang termuat dalam Tabel 1, di bawah ini:

Tabel 1

Kualifikasi Nilai

\begin{tabular}{|c|c|c|}
\hline No. & Skor & Kualifikasi \\
\hline 1 & $81-100$ & Amat Baik \\
\hline 2 & $61-80$ & Baik \\
\hline 3 & $41-60$ & Cukup baik \\
\hline 4 & $21-40$ & Kurang baik \\
\hline 5 & $0-20$ & Amat kurang baik \\
\hline
\end{tabular}

Dengan demikian, berdasarkan uraian di atas, analisis data dapat dilakukan melalui langkahlangkah berikut (1) menyusun data berdasarkan kategori tertentu, yakni hasil tes berdasarkan kelompok responden berdasarkan sebaran jawaban perbutir soal, dan secara kumulatif terhadap seluruh responden; (2) melakukan pemeriksaan keabsahan data melalui metode triangulasi teori dan triangulasi sumber untuk memverifikasi data; (3) mendeskripsikan serta menjelaskan temuan-temuan melalui penhitungan kuantum terhadap data hasil tes responden penelitian; dan (4) menarik kesimpulan, termasuk rekomendasi tindakan-tindakan atau kebijakkan-kebijakan yang dapat diambil, sesuai dengan hasil penelitian.

\section{Paparan Data dan Pembahasan}

3.1 Observasi terhadap Responden

Selama penyebaran instrumen penelitian, peneliti bertindak sekaligus sebagai pengamat yang berinteraksi secara pasif dan terbatas dengan para responden dengan kategori pemuda yang memiliki rentang usia 16-30 tahun, serta berdomisili pada kedua wilayah yang menjadi lokasi penelitian. Seluruh responden adalah penutur aktif bahasa Melayu Ambon (BMA), yakni sebagai bahasa pertama atau bahasa Ibu, selain bahasa daerah sebagai bahasa kedua.

Kehadiran peneliti diketahui oleh responden. Namun, peneliti hanya bertindak sebagai pengamat pada saat pengambilan data di lapangan. Peneliti juga membatasi interaksi responden dengan pihak lain di luar kepentingan penelitian (jika ada) pada saat 
pengisian instrumen. Hal tersebut dilakukan dengan cara meminta para responden untuk mengisi lembar jawaban tanpa bertanya kepada siapapun yang ada di sekitar mereka. Dengan demikian, untuk mendukung perhitungan data secara statistik, kesan peneliti terhadap responden selama pengisian instrumen menjadi penting dan signifikan untuk dibahas di dalam laporan ini.

Berdasarkan pengamatan acak yang dilakukan oleh peneliti terhadap para responden yang dipilih, dapat dikemukakan bahwa seluruh responden terlihat mengalami kesulitan dalam mengisi jawaban pada instrumen penelitian yang diberikan. Meskipun peneliti tidak secara ketat menetapkan batas waktu pengisian instrumen penelitian, secara umum para responden terlihat membutuhkan waktu yang lebih lama untuk mengisi jawaban-jawaban pada instrumen penelitian. Menurut hasil uji instrumen oleh peneliti, waktu ideal yang dibutuhkan untuk menjawab satu soal rata-rata berkisar 20-30 detik sehingga waktu maksimal yang dibutuhkan untuk menjawab 20 soal adalah 10 menit. Sebaliknya, rata-rata para responden membutuhkan waktu lebih dari 20 menit untuk mengerjakan 20 soal tertutup yang disiapkan dalam instrumen penelitian.

Tanda-tanda

lainnya

yang

mengindikasikan para responden mengalami kesulitan mengisi instrumen, yakni wajah berkerut, bahasa tubuh yang menandakan kebosanan, dan ekspresi wajah yang datar tanpa tersenyum. Bahkan, ada beberapa responden yang menyatakan keinginan untuk berhenti dan menyerahkan hasil kerjanya dengan beberapa soal yang tidak terisi. Responden-responden tersebut baru bersedia mengerjakan sampai selesai setelah dimotivasi oleh peneliti. Mereka mengakui bahwa mereka terpaksa memilih jawaban secara acak mengikuti intuisi karena tidak memahami kata-kata yang tercantum di dalam instrumen penelitian tersebut.

Selanjutnya, komentar-komentar responden juga diperhatikan dan dicatat dengan teliti dan terperinci oleh peneliti. Sebagian besar responden secara spontan mengucapkan kata susah, kalimat beta seng
mangarti"Saya tidak mengerti." atau Ini maksudnya apa e?" Apa maksudnya (kalimat/kata) ini, ya?". Ada pula responden yang secara terus-terang menjelaskan bahwa kata-kata yang ada di dalam instrumen penelitian adalah kata-kata yang sama sekali belum pernah atau tidak pernah diketahui dan tidak pernah digunakan dalam tuturan seharihari.

\subsection{Pengujian Hipotesis}

Pengujian hipotesis dalam penelitian ini dilakukan sesudah perhitungan statistik dengan menggunakan rumus yang telah ditentukan sehingga akan terlihat relevansi antara pengukuran data dan uraian-uraian deskriptif dengan hipotesis yang telah ditetapkan sebelumnya. Penghitungan data akan dilakukan melalui pendekatan parsial, yakni penghitungan pada masing-masing kelompok responden (Negeri Batu Merah dan Negeri Galala-Hative Kecil) dan penghitungan secara kumulatif dari (total jumlah kedua negeri secara keseluruhan) untuk menentukan hasil dari keseluruhan responden.

Adapun penghitungan dimaksud dilakukan dalam beberapa langkah, antara lain: (1) menyajikan rata-rata dari data mentah yang dihimpun dari hasil tes responden; (2) menentukan nilai tertinggi dan terrendah; (3) menghitung frekuensi setiap nilai kemudian menyajikan dalam tabel distribusi frekuensi; (4) menghitung nilai rata-rata keseluruhan dengan menggunakan rumus yang telah ditentukan; dan (5) menguji hipotesis berdasarkan hasil perhitungan. Langkahlangkah pengujian hipotesis sebagaimana disebutkan di atas akan disajikan secara terperinci dan sistematis dalam uraian-uraian di bawah ini.

Langkah pertama, menyajikan data mentah hasil tes melalui instrumen pengukuran, yakni soal-soal tes. Adapun nilai rata-rata keseluruhan adalah seperti yang tertera pada Tabel 2, 3, dan 4 di bawah ini.

Tabel 2

Data Nilai Rata-Rata Tes Responden Negeri Batu Merah

\begin{tabular}{|c|c|c|c|c|}
\hline \multicolumn{4}{|c|}{ Nilai Rata-Rata Keseluruhan } \\
\hline 40 & 35 & 45 & 30 & 45 \\
\hline
\end{tabular}




\begin{tabular}{|l|l|l|l|l|}
\hline 40 & 30 & 25 & 35 & 45 \\
\hline 35 & 40 & 40 & 50 & 35 \\
\hline 20 & 35 & 30 & 35 & 35 \\
\hline 20 & 45 & 25 & 25 & 40 \\
\hline 35 & 35 & 25 & 50 & 35 \\
\hline 40 & 25 & 35 & 45 & 20 \\
\hline 25 & 45 & 30 & 10 & 25 \\
\hline 30 & 40 & 25 & 40 & 45 \\
\hline 40 & 40 & 20 & 30 & 35 \\
\hline 25 & 45 & 30 & 25 & 35 \\
\hline 30 & 30 & 40 & 15 & 35 \\
\hline 10 & 40 & 45 & 25 & 45 \\
\hline 25 & 40 & 30 & 45 & 40 \\
\hline 20 & 20 & 20 & 45 & 25 \\
\hline 50 & 35 & 15 & 20 & 30 \\
\hline 35 & 35 & 20 & 35 & 40 \\
\hline 45 & 30 & 25 & 25 & 25 \\
\hline 25 & 30 & 30 & 35 & 35 \\
\hline 25 & 25 & 25 & 35 & 45 \\
\hline$S 4$
\end{tabular}

Sumber: Data hasil penelitian

Tabel 3

Data Nilai Rata-Rata Tes Responden Negeri Galala - Hative Kecil

\begin{tabular}{|c|c|c|c|c|}
\hline \multicolumn{5}{|c|}{ Nilai Rata-Rata Keseluruhan } \\
\hline 35 & 25 & 35 & 25 & 35 \\
\hline 45 & 5 & 35 & 30 & 70 \\
\hline 25 & 35 & 20 & 15 & 70 \\
\hline 55 & 30 & 20 & 20 & 50 \\
\hline 20 & 55 & 25 & 15 & 25 \\
\hline 25 & 50 & 35 & 30 & 25 \\
\hline 10 & 25 & 20 & 45 & 20 \\
\hline 50 & 25 & 20 & 45 & 35 \\
\hline 35 & 15 & 30 & 50 & 35 \\
\hline 35 & 25 & 45 & 50 & 20 \\
\hline 30 & 20 & 60 & 35 & 25 \\
\hline 45 & 40 & 25 & 45 & 45 \\
\hline 25 & 30 & 30 & 50 & 35 \\
\hline 0 & 45 & 30 & 45 & 35 \\
\hline 40 & 15 & 45 & 50 & 45 \\
\hline 40 & 45 & 45 & 40 & 15 \\
\hline 25 & 25 & 55 & 45 & 40 \\
\hline 65 & 15 & 50 & 40 & 30 \\
\hline 35 & 35 & 50 & 55 & 20 \\
\hline 25 & 45 & 30 & 55 & 20 \\
\hline
\end{tabular}

Sumber: Data hasil penelitian
Tabel 4

Total Data Nilai Rata-Rata Tes Seluruh Responden

Nilai Rata-Rata Keseluruhan

\begin{tabular}{|l|l|l|l|l|l|l|l|l|l|}
\hline 40 & 35 & 45 & 30 & 45 & 35 & 25 & 35 & 25 & 35 \\
\hline 40 & 30 & 25 & 35 & 45 & 45 & 5 & 35 & 30 & 70 \\
\hline 35 & 40 & 40 & 50 & 35 & 25 & 35 & 20 & 15 & 70 \\
\hline 20 & 35 & 30 & 35 & 35 & 55 & 30 & 20 & 20 & 50 \\
\hline 20 & 45 & 25 & 25 & 40 & 20 & 55 & 25 & 15 & 25 \\
\hline 35 & 35 & 25 & 50 & 35 & 25 & 50 & 35 & 30 & 25 \\
\hline 40 & 25 & 35 & 45 & 20 & 10 & 25 & 20 & 45 & 20 \\
\hline 25 & 45 & 30 & 10 & 25 & 50 & 25 & 20 & 45 & 35 \\
\hline 30 & 40 & 25 & 40 & 45 & 35 & 15 & 30 & 50 & 35 \\
\hline 40 & 40 & 20 & 30 & 35 & 35 & 25 & 45 & 50 & 20 \\
\hline 25 & 45 & 30 & 25 & 35 & 30 & 20 & 60 & 35 & 25 \\
\hline 30 & 30 & 40 & 15 & 35 & 45 & 40 & 25 & 45 & 45 \\
\hline 10 & 40 & 45 & 25 & 45 & 25 & 30 & 30 & 50 & 35 \\
\hline 25 & 40 & 30 & 45 & 40 & 0 & 45 & 30 & 45 & 35 \\
\hline 20 & 20 & 20 & 45 & 25 & 40 & 15 & 45 & 50 & 45 \\
\hline 50 & 35 & 15 & 20 & 30 & 40 & 45 & 45 & 40 & 15 \\
\hline 35 & 35 & 20 & 35 & 40 & 25 & 25 & 55 & 45 & 40 \\
\hline 45 & 30 & 25 & 25 & 25 & 65 & 15 & 50 & 40 & 30 \\
\hline 25 & 30 & 30 & 35 & 35 & 35 & 35 & 50 & 55 & 20 \\
\hline 25 & 25 & 25 & 35 & 45 & 25 & 45 & 30 & 55 & 20 \\
\hline
\end{tabular}

Sumber: Data hasil penelitian

Kedua, peneliti menentukan skor tertinggi dari data tes responden baik secara parsial maupun secara akumulatif. Skor terendah dan tertinggi akan ditampilkan dalam Tabel 5 di bawah ini.

Tabel 5

Nilai Tes Terendah dan Tertinggi

\begin{tabular}{|l|c|c|c|}
\hline Uraian & $\begin{array}{c}\text { Negeri } \\
\text { Batu } \\
\text { Merah }\end{array}$ & $\begin{array}{c}\text { Negeri } \\
\text { Galala- } \\
\text { Hative } \\
\text { Kecil }\end{array}$ & Keseluruhan \\
\hline $\begin{array}{l}\text { Nilai } \\
\text { Terendah }\end{array}$ & 10 & 0 & 0 \\
\hline $\begin{array}{l}\text { Nilai } \\
\text { Tertinggi }\end{array}$ & 50 & 70 & 70 \\
\hline
\end{tabular}

Sumber: Data hasil penelitian

Ketiga, menghitung frekuensi dari setiap nilai yang telah dihitung dari data mentah tes responden (Tabel 2, 3, dan 4) kemudian ditabulasikan ke dalam tabel distribusi frekuensi. Tabel distribusi frekuensi akan disajikan baik menurut kelompok responden (secara terpisah), maupun secara keseluruhan. 
Nilai frekuensi untuk setiap nilai yang terdistribusi dengan cara mengalikan masingmasing nilai baku dengan frekuensi dari nilai tersebut. Total nilai frekuensi diperoleh dari penjumlahan nilai frekuensi dari masing- masing kelompok responden, yakni responden dari Negeri Batu Merah dan responden dari Negeri Galala-Hative Kecil. Selanjutnya, distribusi frekuensi dari data akan ditampilkan secara terperinci dalam Tabel 6 berikut ini.

\section{Tabel 6}

Distribusi Frekuensi Nilai

Responden Per Kelompok dan Kumulatif

\begin{tabular}{|c|c|c|c|c|c|c|c|}
\hline \multicolumn{3}{|c|}{$\begin{array}{c}\text { Negeri } \\
\text { Batu Merah }\end{array}$} & \multicolumn{3}{|c|}{$\begin{array}{c}\text { Negeri Galala - Hative } \\
\text { Kecil }\end{array}$} & \multirow[t]{2}{*}{$\begin{array}{c}\text { Total } \\
\text { Frekuensi }\end{array}$} & \multirow{2}{*}{$\begin{array}{c}\text { Total } \\
\text { Nilai } \\
\text { Frekuensi }\end{array}$} \\
\hline Nilai & Frekuensi & $\begin{array}{l}\text { Nilai } \\
\text { Frek. }\end{array}$ & Nilai & Frekuensi & $\begin{array}{l}\text { Nilai } \\
\text { Frek. }\end{array}$ & & \\
\hline 100 & 0 & 0 & 100 & 0 & 0 & 0 & 0 \\
\hline 95 & 0 & 0 & 95 & 0 & 0 & 0 & 0 \\
\hline 90 & 0 & 0 & 90 & 0 & 0 & 0 & 0 \\
\hline 85 & 0 & 0 & 85 & 0 & 0 & 0 & 0 \\
\hline 80 & 0 & 0 & 80 & 0 & 0 & 0 & 0 \\
\hline 75 & 0 & 0 & 75 & 0 & 0 & 0 & 0 \\
\hline 70 & 0 & 0 & 70 & 2 & 140 & 2 & 140 \\
\hline 65 & 0 & 0 & 65 & 1 & 65 & 1 & 65 \\
\hline 60 & 0 & 0 & 60 & 1 & 65 & 1 & 65 \\
\hline 55 & 0 & 0 & 55 & 5 & 275 & 5 & 275 \\
\hline 50 & 3 & 150 & 50 & 9 & 450 & 12 & 600 \\
\hline 45 & 14 & 630 & 45 & 15 & 675 & 29 & 1305 \\
\hline 40 & 15 & 600 & 40 & 6 & 240 & 21 & 480 \\
\hline 35 & 21 & 735 & 35 & 15 & 525 & 36 & 1260 \\
\hline 30 & 14 & 420 & 30 & 10 & 300 & 24 & 720 \\
\hline 25 & 20 & 500 & 25 & 16 & 400 & 36 & 900 \\
\hline 20 & 9 & 180 & 20 & 11 & 220 & 20 & 400 \\
\hline 15 & 2 & 30 & 15 & 6 & 90 & 8 & 120 \\
\hline 10 & 2 & 20 & 10 & 1 & 10 & 3 & 30 \\
\hline 5 & 0 & 0 & 5 & 1 & 5 & 1 & 5 \\
\hline $\mathbf{0}$ & 0 & 0 & 5 & 1 & 5 & 1 & 5 \\
\hline \multicolumn{2}{|c|}{$\sum=100$} & 3265 & \multicolumn{3}{|c|}{$\sum=100$} & $\sum=200$ & 6370 \\
\hline
\end{tabular}

Sumber: Data hasil penelitian

Keempat, menentukan nilai rata-rata dari nilai frekuensi yang telah diterakan pada tabel distribusi di atas.Penentuan nilai rata-rata tersebut pertama-tama dilakukan terhadap data nilai masing-masing kelompok responden. Hal tersebut bertujuan agar perbandingan data dan nilai antarkedua kelompok responden dapat tersaji secara terperinci sebelum disajikan perhitungan secara kumulatif. Setelah penentuan nilai rata-rata kedua kelompok responden, pada tahap akhir akan disajikan perhitungan nilai rata-rata secara kumulatif terhadap seluruh data dari kedua kelompok responden. Perhitungan nilai rata-rata frekuensi dimaksud akan disajikan pada bagian-bagian selanjutnya.

\section{3}

\section{Pembahasan}

Hasil pengukuran penguasaan 200 orang responden dari ketiga negeri atau dua kelompok sasaran penelitian dilakukan dengan menyebarkan sebanyak 200 lembar instrumen penelitian berupa butir soal sebanyak 20 soal dengan cakupan konsep morfologis, sintaksis, dan semantik. 
Tabel 7 berikut ini akan disajikan data distribusi jawaban benar untuk setiap butir instrumen tes untuk kedua kelompok responden.

Tabel 7

Distribusi Jawaban Benar Per Butir Soal

\begin{tabular}{|c|c|c|c|c|c|c|}
\hline \multirow{3}{*}{$\begin{array}{l}\text { Nomor } \\
\text { Soal }\end{array}$} & \multicolumn{4}{|c|}{ Skor Responden } & \multirow{3}{*}{ Rerata } & \multirow{3}{*}{$\begin{array}{c}\text { Keterangan } \\
\begin{array}{c}\sum \text { n001- } \\
\text { n200 }\end{array}\end{array}$} \\
\hline & $\begin{array}{l}\text { Negeri } \\
\text { Batu } \\
\text { Merah }\end{array}$ & \multirow[t]{2}{*}{ Keterangan } & $\begin{array}{l}\text { Negeri } \\
\text { Galala- } \\
\text { Hative } \\
\text { Kecil }\end{array}$ & \multirow[t]{2}{*}{ Keterangan } & & \\
\hline & $\begin{array}{c}\sum \mathrm{n} 001- \\
\mathrm{n} 100\end{array}$ & & $\begin{array}{c}\sum \mathrm{n} 101- \\
\mathrm{n} 200\end{array}$ & & & \\
\hline 1 & 55 & & 29 & & 42,0 & \\
\hline 2 & 12 & & 4 & Terendah & 8,0 & \\
\hline 3 & 7 & & 11 & & 9,0 & \\
\hline 4 & 2 & Terendah & 8 & & 5,0 & Terendah \\
\hline 5 & 57 & & 19 & & 38,0 & \\
\hline 6 & 78 & Tertinggi & 93 & Tertinggi & 85,5 & Tertinggi \\
\hline 7 & 10 & & 16 & & 13,0 & \\
\hline 8 & 30 & & 38 & & 34,0 & \\
\hline 9 & 26 & & 39 & & 32,5 & \\
\hline 10 & 26 & & 42 & & 34,0 & \\
\hline 11 & 14 & & 29 & & 21,5 & \\
\hline 12 & 66 & & 61 & & 63,5 & \\
\hline 13 & 36 & & 57 & & 46,5 & \\
\hline 14 & 24 & & 36 & & 30,0 & \\
\hline 15 & 43 & & 53 & & 48,0 & \\
\hline 16 & 10 & & 16 & & 13,0 & \\
\hline 17 & 45 & & 56 & & 50,5 & \\
\hline 18 & 46 & & 38 & & 42,0 & \\
\hline 19 & 40 & & 31 & & 35,5 & \\
\hline 20 & 47 & & 13 & & 30,0 & \\
\hline
\end{tabular}

Berdasarkan paparan data tes pada Tabel 4.1 Jan 4.2 itu dapat dilihat sebaran skor tes untuk esponden dari Negeri Batu Merah. Skor ertinggi ialah 10 yang diraih oleh tiga orang :esponden (n016, n063, dan n066), sedangkan skor terendah ialah 2 diperoleh oleh dua esponden (n013 dan n068). Sebaliknya, sebaran skor tes untuk responden dari Negeri Galala-Hative Kecil, skor tertinggi ialah 14 yang diperoleh dua responden (n182 dan 1183). Sementara itu, skor terendah ialah 0 yang diperoleh satu orang responden (n114).

Sementara itu, dilihat dari distribusi lawaban benar secara kumulatif untuk setiap sutir soal terdapat distribusi total skor yang sangat fluktuatif dengan rentang antarnilai yang cukup lebar. Paparan rinci distribusi jawaban benar kumulatif responden tersebut
Penyajian ini berguna untuk mendapatkan gambaran fluktuasi skor jawaban benar untuk setiap butir soal. 
responden Negeri Batu Merah (n001-n100) dan sebanyak 11 responden Negeri GalalaHative Kecil (n101-n200) menjawab benar. Secara keseluruhan, rerata kumulatif untuk soal nomor 3 adalah 9,0.

Pada soal nomor 4 yang menguji indikator morfologis, sintaksis, dan semantik secara komprehensif (kelas kata, struktur kalimat), sebanyak 2 jawaban benar dari responden Negeri Batu Merah (n001-n100) dan sebanyak 8 jawaban benar pada responden Negeri Galala-Hative Kecil (n101-n200). Secara keseluruhan, rerata kumulatif untuk soal nomor 4 adalah 5,0. Secara kumulatif, inilah soal dengan rerata jawaban benar responden yang terendah.

Demikian pula dengan soal nomor 5 yang juga menguji indikator morfologis, sintaksis dan semantik secara komprehensif (kelas kata, struktur kalimat).Terdapat fluktuasi kumulatif sebanyak 57 jawaban benar dari responden Negeri Batu Merah (n001-n100) dan sebanyak 19 jawaban benar pada responden Negeri Galala-Hative Kecil (n101-n200). Secara keseluruhan, rerata kumulatif untuk soal nomor 5 adalah 38,0.

Pada soal nomor 6 yang menguji indikator morfologis, sintaksis dan semantik secara komprehensif (kelas kata, struktur kalimat), terdapat sebanyak 78 jawaban benar dari responden Negeri Batu Merah (n001-n100) dan sebanyak 93 jawaban benar pada responden Negeri Galala-Hative Kecil (n101-n200). Secara keseluruhan, rerata kumulatif untuk soal nomor 6 adalah sebesar 85,5. Angka tersebut merupakan rerata kumulatif jawaban benar per butir soal.

Fluktuasi turun tajam pada soal nomor 7 yang menguji indikator morfologis dan semantis (kelas kata, makna). Akumulasi skor menunjukkan terdapat sebanyak 10 jawaban benar dari responden Negeri Batu Merah (n001-n100) dan sebanyak 16 jawaban benar pada responden Negeri Galala-Hative Kecil (n101-n200). Secara keseluruhan, rerata kumulatif untuk soal nomor 7 adalah 13,0.

Selanjutnya, terjadi peningkatan yang signifikan pada soal nomor 8 yang menguji indikator morfologis dan semantis (kelas kata, makna).Terdapat sebanyak 30 jawaban benar dari responden Negeri Batu Merah (n001n100) dan sebanyak 38 jawaban benar pada responden Negeri Galala-Hative Kecil (n101-n200). Secara keseluruhan, rerata kumulatif untuk soal nomor 8 adalah 34,0.

Kecenderungan fluktuasi yang tidak terlalu signifikan terjadi pada soal nomor 9 yang menguji indikator morfologis dan semantis (kelas kata, makna). Pada hasil tes terdapat sebanyak 26 jawaban benar dari responden Negeri Batu Merah (n001-n100) dan sebanyak 39 jawaban benar pada responden Negeri Galala-Hative Kecil (n101-n200). Secara keseluruhan, rerata kumulatif untuk soal nomor 9 adalah 32,5.

Pada soal nomor 10 yang masih menguji indikator morfologis dan semantis (kelas kata, makna) terdapat sedikit peningkatan yakni sebanyak 26 jawaban benar dari responden Negeri Batu Merah (n001-n100) dan sebanyak 42 jawaban benar pada responden Negeri Galala-Hative Kecil (n101-n200). Secara keseluruhan, rerata kumulatif untuk soal nomor 10 adalah 34,0.

Penurunan terjadi pada skor kumulatif soal nomor 11 yang menguji indikator morfologis dan semantis (kelas kata, makna).Terdapat sebanyak 14 jawaban benar dari responden Negeri Batu Merah (n001n100) dan sebanyak 29 jawaban benar pada responden Negeri Galala-Hative Kecil (n101-n200). Dengan demikian, rerata kumulatif untuk soal nomor 11 mengalami penurunan menjadi 21,5.

Pada soal nomor 12 yang menguji indikator morfologis dan semantis (kelas kata, makna), terdapat sebanyak 66 jawaban benar dari responden Negeri Batu Merah (n001n100) dan sebanyak 61 jawaban benar pada responden Negeri Galala-Hative Kecil (n101-n200). Rerata kumulatif untuk soal nomor 12 cukup stabil pada angka 63,5.

Selanjutnya, terjadi sedikit penurunan angka kumulatif jawaban benar pada soal nomor 13 yang menguji indikator morfologis dan semantis (kelas kata, makna). Pada soal nomor 13 terdapat sebanyak 36 jawaban benar dari responden Negeri Batu Merah (n001n100) dan sebanyak 57 jawaban benar pada responden Negeri Galala-Hative Kecil 
(n101-n200). Secara keseluruhan, rerata kumulatif untuk soal nomor 13 adalah 46,5.

Pada soal nomor 14 yang menguji indikator morfologis dan semantis (makna kata), secara kumulatif terdapat sebanyak 24 jawaban benar dari responden Negeri Batu Merah (n001-n100) dan sebanyak 36 jawaban benar pada responden Negeri GalalaHative Kecil (n101-n200). Rerata kumulatif untuk soal nomor 14 adalah sebanyak 30,0.

Selanjutnya, soal 15 yang menguji indikator morfologis dan semantis (makna kata) memiliki hasil secara kumulatif meningkat sebanyak 43 jawaban benar dari responden Negeri Batu Merah (n001-n100) dan sebanyak 53 jawaban benar pada responden Negeri Galala-Hative Kecil (n101-n200) Dengan demikian, rerata kumulatif untuk soal nomor 15 adalah 48,0.

Pada soal nomor 16 yang menguji indikator morfologis dan semantis (kelas kata, makna kata), secara kumulatif terdapat penurunan skor, yakni sebanyak 10 jawaban benar dari responden Negeri Batu Merah (n001—n100) dan sebanyak 16 jawaban benar pada responden Negeri Galala-Hative Kecil (n101-n200). Rerata kumulatif untuk soal nomor 16 adalah sebanyak 13,0.

Pada soal nomor 17 yang juga menguji indikator morfologis dan semantis (kelas kata, makna kata), secara kumulatif terdapat peningkatan skor sebanyak 45 jawaban benar dari responden Negeri Batu Merah (n001n100) dan sebanyak 56 jawaban benar pada responden Negeri Galala-Hative Kecil (n101-n200). Maka, rerata kumulatif untuk soal nomor 17 adalah sebanyak 50,5.

Hasil perhitungan kumulatif jawaban responden untuk soal nomor 18 menunjukkan kecenderungan yang kurang-lebih sama. Soal nomor 18 menguji indikator morfologis dan semantis (kelas kata, makna kata). Hasilnya, terdapat peningkatan yang amat kecil, yakni 46 jawaban benar dari responden Negeri Batu Merah (n001-n100) dan sebanyak 38 jawaban benar pada responden Negeri GalalaHative Kecil (n101 - n200). Dengan demikian, rerata kumulatif untuk soal nomor 18 ini adalah sebanyak 42,5 .
Pada soal nomor 19 yang juga menguji indikator morfologis, sintaksis, dan semantis (jenis kata, struktur kalimat, makna kata), secara kumulatif terdapat peningkatan skor sebanyak 40 jawaban benar dari responden Negeri Batu Merah (n001-n100) dan sebanyak 31 jawaban benar pada responden Negeri Galala-Hative Kecil (n101-n200) Rerata kumulatif jawaban responden untuk soal nomor 19 adalah sebanyak 35,5.

Akhirnya, fluktuasi skor yang cukup tajam kembali terlihat pada soal nomor 20 yang juga menguji indikator morfologis (morfem dan partikel). Hasil perhitungan menunjukkan bahwa terdapat 47 jawaban benar dari responden Negeri Batu Merah (n001-n100) dan sebanyak 13 jawaban benar pada responden Negeri Galala-Hative Kecil (n101-n200). Rerata kumulatif jawaban responden untuk soal nomor 20 adalah sebanyak 30,0.

Berdasarkan uraian di atas, secara keseluruhan dapat disimpulkan bahwa jumlah persentasi jawaban benar secara kumulatif dari responden terbanyak secara keseluruhan dicapai pada butir soal nomor 6 ( 78 responden Batu Merah dan 93 responden Galala-Hative Kecil). Sementara itu, jawaban benar secara kumulatif paling sedikit atau terendah secara keseluruhan ditemukan pada soal nomor 4 (2 responden Batu Merah) dan soal nomor 2 (4 responden Galala-Hative Kecil). Rerata tertinggi adalah pada soal nomor $6(85,5$ responden) dan rerata terendah $(5,0$ responden).

Perhitungan rata-rata kelas untuk kelompok responden Negeri Batu Merah (n001-n100) adalah:

$X=\frac{\sum X}{N}$

$X=\frac{3265}{100}=\mathbf{3 2 , 6 5}$

Berdasarkan perhitungan di atas, nilai rata-rata penguasaan leksikon arkais bahasa Melayu Ambon pada responden di Negeri Batu Merah berada pada angka 32,65. Berdasarkan angka tersebut, dapat dikatakan bahwa penguasaan 
kelompok responden Negeri Batu Merah berada pada kategori kurang baik.

Perhitungan rata-rata kelas untuk kelompok responden Negeri Galala-Hative Kecil (n101-n200) adalah:

$X=\frac{\sum X}{N}$

$X=\frac{3465}{100}=\mathbf{3 4 , 6 5}$

Perhitungan di atas menunjukkan bahwa nilai rata-rata penguasaan leksikon arkais bahasa Melayu Ambon pada responden di Negeri Galala-Hative Kecil, yaitu 34,65. Berdasarkan angka tersebut, dapat ditetapkan bahwa penguasaan kelompok responden Negeri Galala-Hative Kecil berada pada kategori kurang baik.

Pada akhirnya, perhitungan rata-rata kelas untuk keseluruhan data dari responden Negeri Batu Merah maupun responden Negeri GalalaHative Kecil (n001—n200) sebagai berikut:

$X=\frac{\sum X}{N}$

$X=\frac{6370}{200}=\mathbf{3 1 , 8 5}$

Berdasarkan angka di atas, dapat disimpulkan bahwa penguasaan leksikon arkais Melayu Ambon pada kalangan pemuda di Kecamatan Sirimau, Kota Ambon berada pada kategori kurang baik.

Hasil perhitungan data yang menunjukkan nilai rata dan kategori kurang baik. Hipotesis penelitian ini menyatakan bahwa tingkat penguasaan leksikon arkais bahasa Melayu Ambon berada pada kategori cukup baik. Padahal, hasil perhitungan menunjukkan sebaliknya, penguasaan responden secara kumulatif berkisar pada nilai rata-rata 31,85 (dari skala terbesar 100) dan berada pada kategori kurang baik.

\section{Simpulan}

Berdasarkan temuan-temuan, baik melalui observasi terhadap responden maupun perhitungan terhadap data mentah hasil tes responden, dapat disimpulkan sebagai berikut.

1. Berdasarkan observasi responden ditemukan kesan umum peneliti mengenai adanya kesulitan atau keterbatasan yang cukup signifikan dan cukup memengaruhi para responden dalam mengerjakan soal-soal yang diberikan, terutama menyangkut alokasi waktu yang diperlukan serta keadaan lainnya yang dapat diamati dari para responden.

2. Berdasarkan perhitungan yang telah dilakukan, nilai rata-rata yang menunjukkan penguasaan leksikon arkais bahasa Melayu Ambon pada responden di Negeri Batu Merah berada pada angka 32,65. Berdasarkan angka tersebut, dapat ditetapkan bahwa penguasaan kelompok responden Negeri Batu Merah berada pada kategori kurang baik.

3. Perhitungan lainnya menunjukkan bahwa nilai rata-rata yang menunjukkan tingkat penguasaan leksikon arkais bahasa Melayu Ambon pada responden di Negeri GalalaHative Kecil berada pada angka 34,65, yakni berada pada kategori kurang baik.

4. Secara keseluruhan, hasil perhitungan kumulatif dengan hasil rata-rata 31,85 menunjukkan bahwa penguasaan leksikon arkais Melayu Ambon pada kalangan pemuda di Kecamatan Sirimau, Kota Ambon, juga berada pada kategori kurang baik.

5. Dengan demikian, hipotesis penelitian yang menyatakan bahwa penguasaan leksikon arkais pemuda di Kecamatan Sirimau berada pada kategori cukup baik, ternyata ditolak.

\section{Daftar Pustaka}

Arikunto. (2005). Metode Penelitian:Populasi dan Sampel.Yogyakarta: Pustaka Pelajar. Kadir, Hatib Abdul. (2009). Bergaya di Kota Konflik-Mencari Akar Konflik Ambon Melalui Gaya Hidup Anak Muda.Yogyakarta: Pustaka Pelajar. . (2009). "Nyong Ambon Punya Gaya": Imajinasi Gaya dan Identitas Tubuh Anak Muda Kota Ambon". Makalah disampaikan dalam diskusi buku "Bergaya di Kota Konflik-Mencari Akar Konflik Ambon Melalui Gaya Hidup Anak Muda" tanggal 26 Maret 2009. Salatiga: Pusat Studi Kawasan 
Timur Indonesia Universitas Kristen

Satya Wacana.

Latupapua, F. E., dkk. (2012). Kapata: Sastra

Lisan di Maluku Tengah. Ambon: Balai

Pengkajian Nilai Budaya Provinsi

Maluku dan Maluku Utara. (2013). "Pemertahanan bahasa

Tana sebagai bahasa Adat di Kabupaten Maluku Tengah". Laporan Penelitian Hibah Bersaing pada Lembaga Penelitian Universitas Pattimura: Tidak diterbitkan.

Nurgiyantoro, Burhan. (1987). Penilaian Dalam Pengajaran bahasa dan Sastra. Yogyakarta: BPTE.

Omar, Asmah Hj. (1991). Bahasa Melayu Abad Ke-16: Satu Analisis Berdasarkan Teks Melayu Aqaid al-Nasafi. Kuala Lumpur: Dewan bahasa dan Pustaka.

Patton, Michael Quinn. (2011). Metode Evaluasi Kualitatif. Jakarta: Patawa Publishing.

Pesiwarissa, Leonora F. (2009). "Konstituen "e" dalam bahasa Melayu Ambon (Suatu Kajian Sintaksis). Skripsi Program Studi Pendidikan bahasa dan Sastra Indonesia, Jurusan bahasa dan Seni Fakultas Keguruan dan Ilmu Pendidikan Universitas Pattimura Ambon".

Rustanto, Bambang. (2010). Penelitian Kualitatif. Yogyakarta: Sabda.

Sudjana. (1987). Statistik Deskriptif. Bandung: Tarsito.

Sumarsono dan Painah Partana. (2004). Sosiolinguistik. Yogyakarta: Sabda.

Sugiyono. (2012). Metode Penelitian Kuantitatif Kualitatif dan R\&D. Bandung: Alfabeta.

Sumber laman:

http://alukmalay.blogspot.com/2013/10/pemud a-dalam-proses-html? $\mathrm{m}=1$. Pengertian Pemuda. Diakses tanggal 10 Mei 2015, Pukul 11.48.

http://kbbi.web.id. Kamus Besar Bahasa Indonesia online. Diakses tanggal 14 Mei, Pukul. 17.15 WIT. 